\title{
PENGARUH KUALITAS LAYANAN DAN HARGA TERHADAP LOYALITAS PELANGGAN DENGAN KEPUASAN PELANGGAN SEGABAI VARIABEL INTERVENING PADA PENGGUNA OJEK ONLINE GRAB (STUDI PADA MAHASISWA STIE TAMANSISWA BANJARNEGARA)
}

\author{
Manajemen \\ Lustono $^{1 *}$, Rizki Darmawan ${ }^{2}$ \\ ${ }^{1,2}$ Sekolah Tinggi Ilmu Ekonomi Tamansiswa Banjarnegara \\ Email : lustonots@gmail.com¹, darmawankiki23@gmail.com²
}

\begin{abstract}
This study aims to determine the effect of service quality with price on customer loyalty through customer satisfaction as an intervening variable. STIE Tamansiswa Banjarnegara case study. In this study the independent variable consists of service quality and price, the intervening variable is customer satisfaction and the dependent variable is customer loyalty.

The population of this study is 203 the total number of active students of STIE Tamansiswa Banjarnegara. While the sample of this study was 135 respondents. With accidental sampling technique. The type of research data is primer and data collection techniques using questionnaires.

The results showed that partially the quality of service did not have a significant positive effect on customer loyalty. Price has a significant positive effect on customer loyalty. Service quality has a significant positive effect on customer satisfaction. Price has a significant positive effect on customer satisfaction. Customer satisfaction has a positive effect on customer loyalty. Customer satisfaction does not mediate the relationship between customer satisfaction and customer loyalty. Customer satisfaction can mediate a negative relationship between price and customer loyalty.
\end{abstract}

Keywords: Service quality, Price, Customer satisfaction, Customer loyalty

\section{PENDAHULUAN}

\section{Latar Belakang}

Jasa transportasi saat ini dirasakan sebagai sarana yang sangat penting digunakan dalam kehidupan masyarakat, transportasi digunakan setiap masyarakat untuk memperlancar aktivitas sehari-hari. Dalam melakukan aktivitas rutin setiap hari setiap orang tentu membutuhkan transportasi dalam berbagai kegiatanya seperti bekerja, bersekolah, bepergian maupun aktivitas lainya.

Menurut masyarakat kehadiran Grab dianggap sebagai salah satu bentuk kemudahan dalam mengguanakan layanan jasa secara praktis. Terlebih lagi jasa layanan Grab dilengkapi dengan berbagai fasilitas unggulan yang memberikan nilai lebih bagi para pelanggan.

Pada zaman sekarang perkembangan teknologi informasi sangatlah cepat. Seiring dengan berjalannya waktu perkembangan teknologi menjadi penting karena mempermudah manusia dalam melakukan berbagai kegiatan. memasuki era revolusi industri 4.0 salah satu teknologi yang sudah menjadi megatrend adalah penggunaan internet. Dengan melihat peluang bisnis berbasis internet yang sangat menjanjikan membuat pelaku bisnis menggabungkan internet dan 
transportasi, seperti ojek online. PT. Grab Indonesia merupakan perusahaan yang memimpin revolusi industri transportasi ojek di Indonesia. .

Dengan hal ini, jasa ojek online Grab telah ada di masyarakat Indonesia dan sekarang Grab telah menjadi trend di kalangan masyarakat yang memiliki kegiatan rutinitas sehari-hari. Grab juga memiliki banyak pesaing yang menyediakan layanan yang sama pada sektor transportasi seperti Go-Jek, Oke Jack, INDO-JEK dan HelooJek. Namun ojek online yang sedang trend $\mathrm{di}$ Banjarnegara yakni Grab.

Dengan adanya Grab dapat mempermudah masyarakat Banjarnegara untuk menggunakan transportasi online. Berdasarkan wawancara dengan pengguna aplikasi Grab, terdapat persoalan yang tidak bisa lepas dari transportasi offline antara lain adalah tidak adanya jadwal yang tetap, pola rute transportasi massal yang memaksa pengguna harus transfer atau oper, penumpang yang berlebih saat jam sibuk, kondisi internal dan eksternal yang buruk dan cara mengemudi kendaraan yang sembarangan dan membahayakan keselamatan. Rifusua (2010) menyatakan bahwa transportasi publik yang baik harus memenuhi tiga kriteria dasar, yaitu: kenyamanan, keamanan dan kecepatan.

Salah satu kunci utama dari kesuksesan perusahaan adalah kepuasan konsumen. Pemenuhan kepuasan konsumen menjadi hal yang penting karena kepuasan konsumen ini merupakan strategi bisnis jangka panjang. Dengan konsumen yang puas, maka konsumen cenderung memiliki reaksi yang positif terhadap perusahaan di masa yang akan datang. Menurut Lovelock dan Wirtz (2011) "Kepuasan pelanggan adalah suatu sikap yang diputuskan berdasarkan pengalaman yang didapatkan.

Dengan munculnya fenomena Grab merupakan solusi terbaik dari upaya pemerintah yang belum sanggup menyiapkan transportasi masal yang cepat dan nyaman untuk melayani kegiatan mobilitas sehari-hari masyarakat. Grab memiliki kualitas pelayanan yang sangat berperan dalam kepuasan pelanggan, Menurut Kotler dalam Damayanti dkk (2018) kualitas adalah keseluruhan fitur dan sifat produk atau pelayanan yang berpengaruh pada kemampuannya untuk memuaskan kebutuhan yang dinyatakan atau tersirat. Dengan adanya kualitas yang baik dan memuaskan oleh pelanggan maka akan timbul kepuasan pelanggan yang menyebabkan loyalitas pelanggan terhadap pelayanan jasa transportasi Grab. Menurut 
Biswas (2014), Loyalitas pelanggan merupakan istilah yang digunakan untuk mendeskripsikan perilaku dari pelanggan yang melakukan pembelian ulang, sekaligus mereka membicarakan hal positif mengenai produk atau jasa perusahaan kepada keluarga dan kerabat.

Berbicara tentang kualitas layanan terhadap kepuasan pelanggan Grab terdapat faktor-faktor yang menjadi penyebab terjadinya hal tersebut yaitu terjadinya persaingan harga, kualitas layanan dan banyak pilihan alternatif jasa ojek online lainnya. Menurut Wahyuno dalam Andilala (2018) harga merupakan satuan moneter yang ditukarkan untuk mendapatkan hak milik dan campuran dari barang dan layanan.

Dari penelitian yang dilakukan Yogi Eko Purwanto (dkk) (2018) menyimpulkan bahwa kualitas layanan dan harga berpengaruh signifikan terhadap loyalitas pelanggan, ketika pelanggan puas terhadap kualitas layanan makan akan timbul loyalitas. Sedangkan penelitian yang di lakukan oleh Woro Mardikawati menyimpulkan bahwa kualitas layanan berpengaruh tidak signifikan terhadap loyalitas.

Reva Anggun Nusantara (2018) dalam penelitiannya menyimpulkan ada pengaruh yang signifikan antara harga terhadap loyalitas, sedangkan hasil dari penelitian Malik, et al (2012) menguji pengaruh harga terhadap loyalitas pelanggan dan diperoleh pengaruh yang negatif dan signifikan. Pengaruh negatif diperoleh ketika harga diukur sebagai nilai rill sehingga semakin tinggi harga maka semakin rendah tingkat loyalitas pelanggan.

Hal tersebut, sangat berpengaruh terhadap mobilitas kegiatan mahasiswa STIE Tamansiswa Banjarnegara dalam rutinitas perkuliahan seperti berangkat atau pulang kuliah, dan pesan makanan dengan layanan grab food. Maka dengan hal ini perlu dilakukan suatu penelitian mengenai kualitas layanan dan harga terhadap loyalitas pelanggan melalui kepuasan pelanggan pada jasa ojek online Grab (Studi pada Mahasiswa STIE Tamansiswa Banjarnegara).

\section{Perumusan Masalah}

Berdasarkan latar belakang masalah yang dijelaskan di atas maka rumusan masalah yang akan dibahas dalam penelitian ini adalah:

1. Apakah kualitas layanan berpengaruh terhadap loyalitas pelanggan pada jasa ojek online Grab di STIE Tamansiswa Banjarnegara?

2. Apakah harga berpengaruh terhadap loyalitas pelanggan pada jasa ojek 
online Grab di STIE Tamansiswa Banjarnegara?

3. Apakah kualitas layanan berpengaruh terhadap kepuasan pelanggan pada jasa ojek online Grab di STIE Tamansiswa Banjarnegara?

4. Apakah Harga berpengaruh terhadap kepuasan pelanggan pada jasa ojek online Grab di STIE Tamansiswa Banjarnegara?

5. Apakah kepuasan pelanggan berpengaruh terhadap loyalitas pelanggan pada jasa ojek online Grab di STIE Tamansiswa Banjarnegara?

6. Apakah kualitas layanan berpengaruh terhadap loyalitas pelanggan melalui kepuasan pelanggan pada jasa ojek online Grab di STIE Tamansiswa Banjarnegara?

7. Apakah harga berpengaruh terhadap loyalitas pelanggan melalui kepuasan pelanggan pada jasa ojek online Grab di STIE Tamansiswa Banjarnegara.

\section{Tujuan Penelitian}

Berdasarkan latar belakang masalah yang dijelaskan di atas maka rumusan masalah yang akan dibahas dalam penelitian ini adalah:

1. Apakah kualitas layanan berpengaruh terhadap loyalitas pelanggan pada jasa ojek online Grab di STIE Tamansiswa Banjarnegara?
2. Apakah harga berpengaruh terhadap loyalitas pelanggan pada jasa ojek online Grab di STIE Tamansiswa Banjarnegara?

3. Apakah kualitas layanan berpengaruh terhadap kepuasan pelanggan pada jasa ojek online Grab di STIE Tamansiswa Banjarnegara?

4. Apakah Harga berpengaruh terhadap kepuasan pelanggan pada jasa ojek online Grab di STIE Tamansiswa Banjarnegara?

5. Apakah kualitas layanan berpengaruh terhadap loyalitas pelanggan melalui kepuasan pelanggan pada jasa ojek online Grab di STIE Tamansiswa Banjarnegara?

6. Apakah kualitas layanan berpengaruh terhadap loyalitas pelanggan melalui kepuasan pelanggan pada jasa ojek online Grab di STIE Tamansiswa Banjarnegara?

7. Apakah harga berpengaruh terhadap loyalitas pelanggan melalui kepuasan pelanggan pada jasa ojek online Grab di STIE Tamansiswa Banjarnegara?

\section{METODE PENELITIAN}

\section{Lokasi Penelitian}

Lokasi yang akan di lakukan oleh penelitian ini di Kampus STIE Tamansiswa Banjarnegara (Jl. Mayjen Panjaitan No.29, Krandegan 
Kec.Banjarnegara, Banjarnegara, Jawa Tengah)

\section{Jenis Penelitian}

Penelitian ini menggunakan data kuantitatif dengan pendekatan asosiatif. Penelitian asosiatif merupakan penelitian yang mencari hubungan antara satu variabel dengan variabel lain. Dalam penelitian ini terdapat variabel independent (yang mempengaruhi), variabel dependen (yang dipengaruhi) dan variabel intervening (penghubung).

\section{Variabel Penelitian}

a Variabel bebas (independent variable: Kualitas Layanan $\left(\mathrm{X}_{1}\right)$, Harga $\left(\mathrm{X}_{2}\right)$

b Variabel terikat (dependent variable): Loyalitas Pelanggan (Y)

c Variabel Penghubung (Intervening) Kepuasan Pelanggan (M)

\section{Definisi Konsep dan Operasional Variabel}

a. Loyalitas Pelanggan

Definisi konsep : Loyalitas pelanggan adalah perilaku pembelian ulang semata mata menyangkut pembelian merek tertentu yang sama secara berulang ulang.

b. Kepuasan Pelanggan

Definisi konsep : Kepuasan pelanggan adalah perasaan senang atau kecewa yang muncul setelah membandingkan kinerja (hasil) produk yang dipikirkan terhadap kinerja atau hasil yang diharapkan.

c. Kualitas Layanan

Definisi konsep : Kualitas layanan adalah ukuran seberapa bagus tingkat layanan yang diberikan mampu sesuai dengan ekspektasi pelanggan.

d. Harga

Definisi konsep : Harga dapat menentukan pembelian apabila harga yang ditetapkan harus sesuai dengan apa yang didapatkan konsumen.

\section{Populasi, Sampel dan Teknik Sampel}

a. Populasi penelitian

Populasi dalam penelitian ini adalah seluruh pengguna jasa layanan ojek online Grab di wilayah Kampuas STIE Tamansiswa Banjarnegara yang berjumlah 2-3 orang pada tahun 2019.

b. Sampel Penelitian

Atas dasar ukuran sampel minimal tersebut, maka sampel atau responden dalam penelitian ini adalah sejumlah 135 responden.

c. Teknik Sampel

Teknik pengambilan sampel yang digunakan dalam penelitian ini yaitu menggunakan metode accidental sampling

\section{Teknik Analisis Data}


Adapun teknik analisis data yang digunakan dalam penelitian ini adalah :

\section{a. Uji asumsi klasik}

1. Uji normalitas

2. Uji heterokedastisitas

3. Uji multikolonieritas

b. Uji ketepatan model, terdiri dari :

1. Koefisien Determinasi $\left(\mathrm{R}^{2}\right)$

2. Uji T-Statistik (Uji parsial)

c. Uji hipotesis, Uji hipotesisi pada penelitian ini menggunakan Analisis Regresi Variabel Mediasi dengan Metode Kausal Step, dimana metode ini dikembangkan oleh Baror dan Kenny dalam Suliyanti (2011)

\section{Uji Ketepatan Model}

\section{Hasil Uji Koefisien Determinasi $\left(\mathbf{R}^{2}\right)$}

Tabel 1

Hasil Uji Koefisien Determinasi Model 1

\begin{tabular}{|l|l|r|r|r|r|}
\hline Model & $R$ & R Square & $\begin{array}{c}\text { Adjusted R } \\
\text { Square }\end{array}$ & $\begin{array}{r}\text { Std. Error of } \\
\text { the Estimate }\end{array}$ & $\begin{array}{r}\text { Durbin- } \\
\text { Watson }\end{array}$ \\
\hline 1 &, $570^{2}$ &, 325 &, 314 &, 1.950 & 2.035 \\
\hline
\end{tabular}

Sumber: Data sekunder yang diolah, 2020

Berdasarkan tabel diatas dapat dilihat bahwa nilai $\mathrm{R}$ Square sebesar 0,215 yang artinya variabel kualitas layanan, harga memiliki kontribusi pengaruh terhadap loyalitas pelanggan sebesar $21.5 \%$ dan sisanya $88.5 \%$ dijelaskan oleh variabel lain diluar variabel penelitian.

Tabel 2
Hasil Uji Koefisien Determinasi

Model 2

\begin{tabular}{|l|r|r|r|r|r|}
\hline Model & R & R Square & $\begin{array}{c}\text { Adjusted R } \\
\text { Square }\end{array}$ & $\begin{array}{r}\text { Std. Error of } \\
\text { the Estimate }\end{array}$ & $\begin{array}{r}\text { Durbin- } \\
\text { Watson }\end{array}$ \\
\hline 1 &, $570^{\mathrm{a}}$ &, 325 &, 314 &, 1.950 & 2.035 \\
\hline
\end{tabular}

Sumber: Data sekunder yang diolah, 2020

Berdasarkan tabel diatas dapat dilihat bahwa nilai $\mathrm{R}$ Square sebesar 0,325 yang artinya variabel kualitas layanan dan harga memiliki kontribusi pengaruh terhadap kepuasan pelanggan sebesar $32,5 \%$ dan sisanya yaitu $67,5 \%$ dijelaskan oleh variabel lain diluar variabel penelitian.

Tabel 3

Hasil Uji Koefisien Determinasi Model 3

\begin{tabular}{|c|c|c|c|c|c|}
\hline Model & $R$ & R Square & $\begin{array}{c}\text { Adjusted R } \\
\text { Square }\end{array}$ & $\begin{array}{c}\text { Std. Error of } \\
\text { the Estimate }\end{array}$ & $\begin{array}{c}\text { Durbin- } \\
\text { Watson }\end{array}$ \\
\hline 1 &, $449^{2}$ &, 201 &, 195 & 2.439 & 1.862 \\
\hline
\end{tabular}

Sumber: Data sekunder yang diolah, 2020.

Berdasarkan tabel diatas dapat dilihat bahwa nilai $\mathrm{R}$ Square sebesar 0,449 yang artinya variabel kepuasan pelanggan sebesar $44,9 \%$ dan sisanya $55,1 \%$ dijelaskan oleh variabel lain diluar variabel penelitian.

Tabel 4

Hasil Uji Koefisien Determinasi Model 4

\begin{tabular}{|c|c|c|c|c|c|}
\hline Model & R & R Square & $\begin{array}{c}\text { Adjusted R } \\
\text { Square }\end{array}$ & $\begin{array}{l}\text { Std. Eiror of } \\
\text { the Estimate }\end{array}$ & $\begin{array}{l}\text { Duritin- } \\
\text { Watson }\end{array}$ \\
\hline & $816^{2}$ &, 667 & .652 & 593,53092 & 1,897 \\
\hline
\end{tabular}


Berdasarkan tabel diatas dapat dilihat bahwa nilai $\mathrm{R}$ Square sebesar 0,816 yang artinya variabel kepuasan pelanggan sebesar $81,6 \%$ dan sisanya $18,4 \%$ dijelaskan oleh variabel lain diluar variabel penelitian.

Tabel 5

Hasil Uji Koefisien Determinasi Model 5

\begin{tabular}{|l|r|r|r|r|r|}
\hline Model & $R$ & $R$ Square & $\begin{array}{r}\text { Adjusted R } \\
\text { Square }\end{array}$ & $\begin{array}{r}\text { Std. Error of } \\
\text { the Estimate }\end{array}$ & $\begin{array}{r}\text { Durbin- } \\
\text { Watson }\end{array}$ \\
\hline 1 &, $519^{\mathrm{a}}$ &, 269 &, 190 & 2.341 & 1.905 \\
\hline
\end{tabular}

Sumber: Data sekunder yang diolah, 2020.

Berdasarkan tabel diatas dapat dilihat bahwa nilai $\mathrm{R}$ Square sebesar 0,519 yang artinya variabel kepuasan pelanggan sebesar $51,9 \%$ dan sisanya $48,1 \%$ dijelaskan oleh variabel lain diluar variabel penelitian.

\section{Hasil Uji Analisis Regresi Metode Kausal Step}

\section{Hasil Uji Model 1}

Uji ini menunjukan seberapa jauh pengaruh variabel independen secara individual terhadap variabel dependen.

Dapat dilihat pada tabel berikut:

Tabel 9

Hasil Uji Koefisien Determinasi

Model 1

\begin{tabular}{|c|c|c|c|c|c|c|}
\hline & \multirow[t]{2}{*}{ Model } & \multicolumn{2}{|c|}{$\begin{array}{c}\text { Unstandardized } \\
\text { Coefficients }\end{array}$} & \multirow{2}{*}{\begin{tabular}{|c|}
$\begin{array}{c}\text { Standardized } \\
\text { Coefficients }\end{array}$ \\
Beta \\
\end{tabular}} & \multirow[t]{2}{*}{$\mathrm{T}$} & \multirow[t]{2}{*}{ Sig. } \\
\hline & & B & Std. Error & & & \\
\hline \multirow[t]{3}{*}{1} & (Constant) & 11.054 & 1.759 & & 6.284 &, 000 \\
\hline & $\begin{array}{l}\text { Kualitas } \\
\text { Layanan }\end{array}$ & .026 & .086 &, 025 & .297 &, 767 \\
\hline & Harga &, 222 & .040 & .455 & 5.493 &, 000 \\
\hline
\end{tabular}

Persamaan yang dihasilkan :

$\mathrm{Y}=11.054-0,026 \cdot \mathrm{X}_{1}+0,222 \cdot \mathrm{X}_{2}$

Berdasarkan hasil output pada tabel diatas dapat dilihat bahwa:

\section{Pengaruh kualitas layanan}

\section{terhadap loyalitas}

Terlihat pada tabel model 1 pada variabel kualitas layanan mempunyai $\mathrm{t}$ hitung sebesar 0,297 < t tabel 1,657 dan nilai signifikan sebesar 0,767<0,05 maka Ho diterima dan Ha ditolak.

H1 : Kualitas layanan tidak berpengaruh positif dan tidak signifikan terhadap loyalitas pelanggan.

2. Pengaruh harga terhadap loyalitas pelanggan.

Terlihat pada tabel model 1 pada variabel harga mempunyai $t$ hitung sebesar 5,493 < t tabel 1,567 dan nilai signifikan sebesar $0,000<0,05$ maka Ho diterima dan Ha ditolak.

H2 : Harga berpengaruh positif dan signifikan terhadap loyalitas pelanggan

\section{Hasil Uji Model 2}

Uji ini menunjukan seberapa jauh pengaruh variabel independen secara individual terhadap variabel intervening. Dapat dilihat pada tabel berikut :

Tabel 10 
Hasil Uji Koefisien Determinasi

Model 2

\begin{tabular}{|l|r|r|r|r|r|}
\hline \multirow{2}{*}{ Model } & \multicolumn{2}{|c|}{$\begin{array}{c}\text { Unstandardized } \\
\text { Coefficients }\end{array}$} & $\begin{array}{c}\text { Standardized } \\
\text { Coefficients }\end{array}$ & \multirow{2}{*}{ T } & \multirow{2}{*}{ Sig. } \\
\cline { 2 - 4 } & \multicolumn{1}{c|}{$\mathrm{B}$} & \multicolumn{1}{|c|}{ Std. Error } & \multicolumn{1}{c|}{ Beta } & & \\
\hline (Constant) & 7.021 & 1.414 & & 4.961 & .000 \\
\hline $\begin{array}{l}\text { Kualitas } \\
\text { pelayanan }\end{array}$ & .156 & .069 & .173 & 2.257 & .026 \\
\hline Harga & .204 & .032 & .483 & 6.295 & .000 \\
\hline
\end{tabular}

Sumber: Data sekunder yang diolah, 2020

Persamaan yang dihasilkan :

$M=7.021+0,156 \cdot X_{1}+0,204 . X_{2}$

Berdasarkan hasil output pada tabel di atas dapat dilihat bahwa :

\section{Pengaruh kualitas layanan terhadap kepuasan pelanggan.}

Terlihat pada tabel model 2 pada variabel harga mempunyai $\mathrm{t}$ hitung sebesar $2,257<\mathrm{t}$ tabel 1,567 dan nilai signifikan sebesar $0,000<0,05$ maka Ho diterima dan Ha ditolak.

H3 : Kualitas layanan berpengaruh positif dan signifikan terhadap kepuasan pelanggan.

2. Pengaruh harga terhadap kepuasan pelanggan

Terlihat pada tabel model 2 pada variabel harga mempunyai $\mathrm{t}$ hitung sebesar 6,296 < t tabel 1,567 dan nilai signifikan sebesar $0,000<0,05$ maka Ho diterima dan Ha ditolak.

H4 : Harga berpengaruh positif dan signifikan terhadap kepuasan pelanggan.

\section{Hasil Uji Model 3}

Uji ini menunjukan seberapa jauh pengaruh variabel intervening secara individual terhadap variabel dependen.

Dapat dilihat pada tabel berikut :

Tabel 11

Hasil Uji Koefisien Determinasi

Model 3

\begin{tabular}{|l|l|r|r|c|c|c|}
\hline \multirow{2}{*}{ Model } & \multicolumn{2}{|c|}{$\begin{array}{c}\text { Unstandardized } \\
\text { Coefficients }\end{array}$} & $\begin{array}{c}\text { Standardized } \\
\text { Coefficients }\end{array}$ & \multirow{2}{*}{$\mathrm{t}$} & \multirow{2}{*}{ Sig. } \\
\cline { 2 - 7 } & \multicolumn{1}{|c|}{$\mathrm{B}$} & Std. Error & \multicolumn{1}{c|}{ Beta } & & \\
\hline \multirow{2}{*}{1} & (Constant) & 11.137 & 1.613 & & 6.904 &, 000 \\
\cline { 2 - 7 } & $\begin{array}{l}\text { Kepuasan } \\
\text { pelangan }\end{array}$ & .518 & .089 &, 449 & 5.787 &, 000 \\
\hline
\end{tabular}

Sumber: Data sekunder yang diolah, 2020

Persamaan yang dihasilkan:

$\mathrm{Y}=1.137+.0,518 \mathrm{M}$

Berdasarkan hasil output pada tabel diatas dapat dilihat bahwa :

\section{Pengaruh kepuasan pelanggan terhadap}

\section{loyalitas pelanggan}

Terlihat pada tabel model 3 pada variabel kepuasan pelanggan mempunyai $\mathrm{t}$ hitung sebesar $5,787<\mathrm{t}$ tabel 1,567 dan nilai signifikan sebesar $0,003<0,05$ maka Ho diterima dan Ha ditolak.

H5 : Kepuasan pelanggan berpengaruh positif dan signifikan terhadap loyalitas pelanggan.

\section{Hasil Uji Model 4}

Uji ini menunjukan seberapa jauh pengaruh variabel independen terhadap variabel dependen melalui variabel intervening.

Dapat dilihat pada tabel dibawah ini :

Tabel 12 
Hasil Uji Koefisien Determinasi

Model 4

\begin{tabular}{|c|l|r|r|r|r|r|}
\hline \multirow{2}{*}{ Model } & \multicolumn{2}{|c|}{$\begin{array}{c}\text { Unstandardized } \\
\text { Coefficients }\end{array}$} & $\begin{array}{c}\text { Standardized } \\
\text { Coefficients }\end{array}$ & \multirow{2}{*}{ T } & Sig. \\
\cline { 2 - 5 } & \multicolumn{1}{|c|}{ B } & Std. Error & \multicolumn{1}{c|}{ Beta } & & \\
\hline \multirow{1}{*}{1} & Constant) & 10.737 & 1.839 & & 10,398 &, 000 \\
\cline { 2 - 7 } & $\begin{array}{l}\text { Kualitas } \\
\text { Pelayanan }\end{array}$ & .039 & .086 & .038 & .458 &, 648 \\
\cline { 2 - 5 } & $\begin{array}{l}\text { Kepuasan } \\
\text { Pelanggan }\end{array}$ & .503 & .096 & .435 & 5.247 &, 000 \\
\hline
\end{tabular}

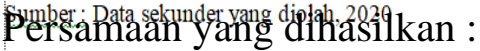

$\mathrm{Y}=10.737-0.039 . \mathrm{X}_{1}+0.503 . \mathrm{M}$

Berdasarkan hasil output pada tabel diatas dapat dilihat bahwa :

\section{a. Pengaruh kualitas layanan terhadap loyalitas pelanggan \\ melalui kepuasan pelanggan.}

1) Terlihat pada tabel model 4 pada variabel kualitas pelayanan mempunyai $\mathrm{t}$ hitung sebesar 0,458 $>\mathrm{t}$ Tabel 1,567 dan nilai signifikan sebesar $0,000<0,05$, maka Ho diterima dan $\mathrm{Ha}$ ditolak.Jadi, dapat disimpulkan kualitas tidak berpengaruh positif signifikan terhadap loyalitas pelanggan.

2) Terlihat pada tabel model 4 pada variabel kepuasan mempunyai $\mathrm{t}$ Hitung 5,247>t Tabel 1,567 dan nilai signifikan sebesar $0,000>$ 0,05 maka Ha ditolak Ho diterima. Jadi, dapat disimpulkan kepuasan pelanggan berpengaruh signifikan terhadap loyalitas.

Diketahui bahwa (1) menjelaskan variabel bebas dan menjelaskan variabel mediasi. pengaruh variabel bebas terhadap variabel terikat tetap tidak berpengaruh signifikan sebelumnya dan setelah memasukan variabel mediasi, namun (1) dan (2) tidak signifikan sehingga dapat disimpulkan kepuasan pelanggan tidak dapat memediasi hubungan antara kualitas layanan dengan loyalitas pelanggan.

H6 : Kepuasan pelanggan tidak dapat memediasi hubungan antara kualitas layanan dengan loyalitas pelanggan.

\section{Hasil Uji Model 5}

Uji ini menunjukan seberapa jauh pengaruh variabel independen terhadap variabel dependen melalui variabel intervening.

Tabel 13

Hasil Uji Koefisien Determinasi Model 5

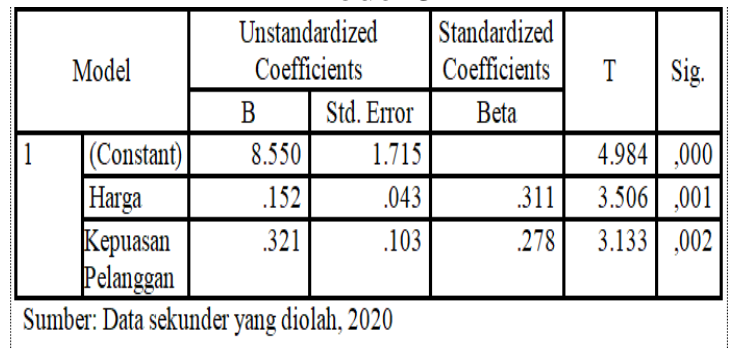

Persamaan yang dihasilkan :

$\mathrm{Y}=8.550+0.152 . \mathrm{X}_{2}+0.321 . \mathrm{M}$

Berdasarkan hasil output pada tabel di atas dapat dilihat bahwa : 
1. Pengaruh harga terhadap loyalitas pelanggan melalui kepuasan pelanggan.

a. Variabel harga mempunyai thitung sebesar 3.506 dengan tabel 1.567. Jadi $t_{\text {hitung }}(3.506)>t_{\text {tabel }}$ (1.567) dapat disimpulkan bahwa harga tidak memiliki kontribusi pengaruh terhadap loyalitas pelanggan. Variabel harga mempunyai nilai signifikan sebesar 0,000. Nilai signifikan $<0,05$ atau nilai $0,000<0,05$, maka Ha diterima dan Ho ditolak. Jadi dapat disimpulkan harga berpengaruh positif dan signifikan terhadap loyalitas pelanggan.

b. Variabel kepuasan pelanggan mempunyai $t_{\text {hitung }}$ sebesar 3,123 dengan tabel 1.567. Jadi thitung (3.123) > tabel (1.567) dapat disimpulkan bahwa kepuasan pelanggan memiliki kontribusi pengaruh positif terhadap loyalitas pelanggan. Variabel kepuasan pelanggan mempunyai nilai signifikan sebesar 0,002 . Nilai signifikan $<0,05$ atau nilai $0,002<$ 0,05, maka Ha diterima dan Ho ditolak. Jadi dapat disimpulkan kepuasan pelanggan berpengaruh positif dan signifikan terhadap loyalitas pelanggan.

H7 : Kepuasan pelanggan dapat memediasi hubungan antara haraga dengan loyalitas pelanggan.

\section{PEMBAHASAN}

\section{Pengaruh kualitas layanan terhadap loyalitas pelanggan}

Lebih luas pelayanan-pelayanan diartikan sebagai serangkaian kegiatan. Karena itu ia merupakan proses. Sebagai proses layanan berlangsung secara rutin dan berkesinambungan meliputi keseluruhan orang dalam masyarakat (Moenir, 2010).

Penelitian yang dilakukan oleh Selvy Normasari dkk (2013) yang berjudul Pengaruh Kualitas Pelayanan terhadap Kepuasan Pelanggan, Citra Perusahaan dan Loyalitas Pelanggan (Survei pada tamu pelanggan yang menginap di Hotel Pelangi Malang). Menyatakan bahwa hasil uji hipotesis kualitas pelayanan tidak berpengaruh dan tidak signifikan terhadap loyalitas pelanggan karena tamu pelanggan tidak bisa loyal apabila belum merasakan kepuasan menginap di Hotel Pelangi Malang.

Kualitas pelayanan merupakan faktor utama yang mempengaruhi loyalitas pelanggan dikarenakan pelanggan yang terpuaskan nilai pribadinya dan mengalami mood yang positif terhadap pelayanan akan memiliki loyalitas yang tinggi 
terhadap perusahaan tersebut. Pelanggan seringkali tidak loyal disebabkan oleh adanya pelayanan yang buruk atau kualitas pelayanan semakin menurun dari yang diharapkan pelanggan.

\section{Pengaruh Harga terhadap Loyalitas}

\section{Pelanggan}

Menurut Effendi M. Guntur (2010) harga adalah sejumlah uang yang ditagihkan atas suatu produk dan jasa atau jumlah dari nilai yang ditukarkan para pelanggan untuk memperoleh manfaat dari memiliki atau menggunakan suatu produk atas jasa. harga merupakan satu-satunya unsur bauran pemasaran yang memberikan pendapatan atau pemasukan.

Dalam penelitian Reva Anggun Nusantara dkk (2018) dengan judul Analisis pengaruh Harga, pelayanan dan persepsi reputasi terhadap loyalitas menggunakan jasa ojek online (Survei pada pelanggan G0-Jek Kota Solo). Menunjukan bahwa uji hipotesis dapat di prediksi berpengeruh terhadap loyalitas pelanggan.

Harga merupakan faktor yang paling penting dalam menentukan keloyalan pelanggan dalam menggunakan barang/jasa. Pelanggan yang pintar akan lebih memilih harga yang terjangkau dengan kualitas yang sesuai dengan apa yang di harapkan.

Pengaruh kualitas layanan terhadap

\section{kepuasan pelanggan}

Menurut Kotler dalam Lupiyoadi (2014) Kualitas layanan adalah setiap tindakan atau kegiatan yang dapat ditawarkan oleh satu pihak kepada pihak lain, pada dasarnya tidak berwujud dan tidak mengakibatkan perpindahan kepemilikan apapun. Produksi jasa mungkin berkaitan dengan produk fisik atau tidak.

Penelitian yang dilakukan oleh Bustam dkk (2017) dengan judul Pengaruh Kualitas Layanan terhadap kepuasan pelanggan Grab-Bike (Studi kasus pada mahasiswa STIEM Bongaya Makasar). Bahwa uji hipotesis yang diteliti terhadap kualitas pelayanan berpengaruh positif signifikan terhadap kepuasan pelanggan.

Kualitas layanan yang baik didalam suatu perusahaan akan menciptakan kepuasan bagi para pelanggannya. Setelah pelanggan merasa puas dengan produk/jasa yang diterimanya, pelanggan akan membandingkan pelayanan yang diberikan. Apabila pelanggan merasa benar-benar puas mereka akan melakukan pembelian ulang serta memberikan rekomendasi kepada orang lain untuk membeli di tempat yang sama.

\section{Pengaruh harga terhadap kepuasan pelanggan.}

Effendi M. Guntur (2010:281) harga adalah sejumlah uang yang ditagihkan atas 
suatu produk dan jasa atau jumlah dari nilai yang ditukarkan para pelanggan untuk memperoleh manfaat dari memiliki atau menggunakan suatu produk atas jasa. Harga merupakan satu-satunya unsur bauran pemasaran yang memberikan pendapatan atau pemasukan bagi perusahaan serta bersifat fleksibel.

Penelitian yang di lakukan oleh Yogi Eko Purwanto dkk (2018) dengan judul Pengaruh harga dan kualitas pelayanan terhadap loyalitas dengan kepuasan konsumen sebagai variable intervening pada pelanggan Grab di Malang (Studi pada mahasiswa kos di kelurahan Tlogomas Malang). Bahwa uji hipotesis yang diteliti berpengaruh positif signifikan terhadap kepuasan konsumen.

Harga adalah alat tukar yang dapat digunakan untuk melakukan pembelian, pelanggan selalu menginginkan harga terbaik dari suatu produk/jasa. Jika harga yang di dapatkan oleh pelanggan sesuai dengan kemampuan dan kualitas yang baik, pelanggan akan merasa puas dengan harga barang/jasa yang telah didapatkan.

\section{Pengaruh kepuasan pelanggan terhadap} loyalitas pelanggan.

Sheth dan Mitta dalam Fandy dan Anastasia (2014) menyatakan, Loyalitas Pelanggan dalam konteks pemasaran jasa didefinisikan sebagai respon yang terkait erat dengan kontinuitas relasi dengan perusahaan, dan biasanya tercermin pembelian berkelanjutan dari penyedia yang sama.

Penelitian yang dilakukan oleh Saniya (2018), dengan judul Pengaruh kepuasan konsumen dalam meningkatkan loyalitas pengguna jasa Grab di daerah Tlogomas Malang. Menunjukan bahwa uji hipotesis berpengaruh secara signifikan terhadap loyalitas pelanggan.

Kepuasan pelanggan berkaitan erat dengan loyalitas pelanggan, apabila pelanggan telah merasa puas dengan suatu produk/jasa. Pelanggan tidak mencari kompetitor dari barang/jasa tersebut.

\section{Pengaruh kualitas layanan terhadap loyalitas pelanggan melalui kepuasan pelanggan.}

Menurut Kotler dalam Lupiyoadi (2014) Kualitas layanan adalah setiap tindakan atau kegiatan yang dapat ditawarkan oleh satu pihak kepada pihak lain, pada dasarnya tidak berwujud dan tidak mengakibatkan perpindahan kepemilikan apapun. Produksi jasa mungkin berkaitan dengan produk fisik atau tidak.

Kepuasan pelanggan adalah tingkat dimana seseorang menyatakan hasil perbandingan atas kinerja produk jasa yang diterima dengan yang diharapkan, Kotler dalam Lupiyoadi (2014). 
Dalam penelitian Lusiah (dkk) (2019) yang berjudul Pengaruh Kualitas Pelayanan terhadap Loyalitas Pelanggan melalui Kepuasan Pelanggan Jasa Transportasi Online. Dari hasil uji hipotesis menunjukan bahwa kepuasan pelanggan tidak dapat memediasi hubungan antara kualitas pelayanan dengan loyalitas pelanggan.

Variabel mediasi kepuasan pelanggan tidak dapat memediasi karena dalam responden dalam penelitian ini adalah mahasiswa. Mahasiswa menggunakan transportasin Online adalah lebih didasarkan karena kebutuhan kegiatan sehari-hari. Mahasiswa mudah berpindah penggunaan dari satu aplikasi ke aplikasi lain dikarenakan tidak adanya biaya berpindah, sehingga tidak ada kendala untuk berpindah. Perusahaan transportasi yang lebih memberikan keuntungan itu lah yang akan di pilih oleh mahasiswa. Sehingga variabel kepuasan palanggan tidak selalu sebagai penentu kualitas pelayanan terhadap loyalitas pelanggan.

Kualitas layanan merupakan faktor utama yang mempengaruhi loyalitas pelanggan, dikarenakan pelanggan yang merasa puas terhadap suatu pelayanan dan mengalami mood yang positif terhadap pelayanan akan memiliki loyalitas yang tinggi terhadap perusahaan.

\section{Pengaruh harga terhadap loyalitas pelanggan melalui kepuasan pelanggan.}

Menurut Effendi M. Guntur (2010) harga adalah sejumlah uang yang ditagihkan atas suatu produk dan jasa atau jumlah dari nilai yang ditukarkan para pelanggan untuk memperoleh manfaat dari memiliki atau menggunakan suatu produk atas jasa. harga merupakan satu-satunya unsur bauran pemasaran yang memberikan pendapatan atau pemasukan bagi perusahaan serta bersifat fleksibel.

Kepuasan pelanggan adalah tingkat dimana seseorang menyatakan hasil perbandingan atas kinerja produk jasa yang diterima dengan yang diharapkan, Kotler dalam Lupiyoadi (2014).

Penelitian yang dilakukan oleh $\mathrm{M}$. Istifau Maulana dkk dengan judul Pengaruh Kualitas Layanan dan Harga Terhadap Loyalitas Pelanggan Melalui Kepuasan Pelanggan Sebagai Variabel Intervening (Studi pada Bus PO. Nusantara Jurusan Solo-Jakarta) menunjukan bahwa uji hipotesis berpengaruh terhadap loyalitas melalui variabel penghubung (Intervening).

Harga yang sesuai dengan kualitas dan kemampuan pelanggan akan menyebabkan kepuasan pelanggan terhadap haraga barang atau jasa yang diperoleh. Pelanggan yang sudah merasa 
puas terhadap barang/jasa akan menimbulkan pembelian ulang terhadap barang/jasa tersebut.

\section{SIMPULAN DAN SARAN}

\section{Kesimpulan}

Berdasarkan hasil penelitian yang dilakukan pada perusahaan PT Grab Indonesia terhadap pelanggan di STIE Tamansiswa Banjarnegara dapat disimpulkan sebagi berikut :

1. Kualitas layanan tidak berpengaruh positif tidak signifikan terhadap loyalitas pelanggan

2. Harga berpengaruh positif dan signifikan terhadap loyalitas pelanggan.

3. Kualitas layanan berpengaruh positif signifikan terhadap kepuasan pelanggan.

4. Harga berpengaruh positif signifikan terhadap kepuasan pelanggan.

5. Kepuasan pelanggan berpengaruh positif signifikan terhadap loyalitas pelanggan.

6. Kepuasan pelanggan tidak dapat memediasi hubungan antara kualitas pelayanan dengan loyalitas pelanggan.

7. Kepuasan pelanggan dapat memediasi hubungan negatif antara harga dengan loyalitas pelanggan.

\section{Saran}

PT Grab Indonesia perlu melakukan upaya sebagai berikut :

1. Perusahaan Grab dalam menjaga kualitas layanan perlu memberikan sosialisasi kepada para driver untuk lebih berhati-hati dalam berkendara dan menaati peraturan rambu-rambu lalulintas.

2. Perusahaan Grab juga harus memberikan peraturan tegas kepada para driver untuk selalu menggunakan atribut berkendara sesuai peraturan untuk menjaga keamanan.

3. Perusahaan Grab harus mensosialisasikan kepada para driver tentang bahaya ugal-ugalan dalam berkendara.

4. PT Grab juga harus mendengarkan keluh kesah pelanggan dan cepat tanggap memperbaiki layanan yang di keluhkan pelanggan untuk menjaga kepuasan pelanggan.

\section{Daftar Pustaka}

Andrieani, Agnes. (2016). Pengaruh Experiental Marketing dan Brand Image Terhadap Minat Berkunjung Kembali, Studi Kasus Pada Keraton Ngayogyakarta Hadiningrat. Skripsi. Yogyakarta: Fakultas Ekonomi Universitas Sanata Dharma.

Ardikawati W., dan Farida N. (2013). Pengaruh Nilai Pelanggan dan Kualitas Layanan Terhadap Loyalitas Pelanggan, Melalui Kepuasan Pelanggan Pada Pelanggan Bus Efisiensi. Jurnal Administrasi Bisnis, 2(1), hal. 64-75.

Biswas, S. (2014). Relationship Marketing: Concepts, Theories, and Cases (Second Edition). Delhi: Asoke K. Ghosh. 
Creswell, J. W. (2010). Research design: pendekatan kualitatif, kuantitatif, dan mixed. Yogyakarta: PT Pustaka Pelajar.

Griffin, Jill. (2016). Customer Loyalty, Menumbuhkan dan Mempertahankan Kesetiaan Pelanggan. Penerbit : Erlangga, Jakarta.

Indriyanti. (2013). Analisis Pengaruh Harga, Promosi dan Kualitas Pelayanan terhadap Keputusan Pembelian Buku di Togamas Jl. Dr. Moewardi 21 Solo. Skripsi. Surakarta :Universitas Muhammadiyah Surakarta

Kotler, Phillip \& Amstrong, Gary. (2012), Dasar-Dasar Pemasaran. Jilid I, Alih Bahasa Alexander Sindoro dan Benyamin Molan, Prenhalindo, Jakarta.

Kotler, Philip and Kevin Lane Keller, (2016). Marketing Managemen, 15th Edition, Pearson Education,Inc.

Moenir. H.A.S. (2010). Manajemen Pelayanan Umum di Indonesia. Bumi Aksara. Jakarta.

Muh. Edo Aprillia Andilala, (2018), Analisis Pengaruh Harga, Persepsi Ukuran, Persepsi Reputasi, dan Kualitas Layanan terhadap Kepercayaan Konsumen dalam Menggunakan Transportasi Online

Mudrajad, Kuncoro. (2013). Mudah Memahami dan menganalisis Indikator ekonomi. Yogyakarta : UPP STIM YKPN

Nurhadi. (2016). Lensa Kegiatan Ekonomi SMA/MA Kelas X. Jakarta: Penerbit Bailmu

Rifusua, Agus Imam. (2010), Analisis Faktor-faktor Yang Mempengaruhi Permintaan Busway di DKI Jakarta Tahun 2004-2008. Tesis Fakultas Ekonomi Universitas Indonesia
Sugiyono (2015). Metode Penelitian Kombinasi (Mix Methods). Bandung: Alfabeta.

Suliyanto, (2011), Ekonometrika TerapanTeori dan Aplikasi dengan SPSS, Penerbit CV.ANDI OFFSET, Yogyakarta.

Tjiptono, Fandy dan Gregorius Chandra, Pemasaran Strategik, Andi. Yogyakarta, (2012)

Zeithaml, V.A., Bitner, M. J. dan Gremler, D. D. (2010). Service Marketing integrating customer focus across the firm (5th ed.) New York: McGrawHill 